\title{
VEŽIMĖLIŲ KREPŠINIO ŽAIDĖJŲ SPECIALIŲJŲ FIZINIŲ GEBĖJIMŲ, AEROBINIO PAJĖGUMO IR ŽAIDIMO RODIKLIŲ KAITA AMŽIAUS, ŽAIDIMO STAŽO IR NEGALIOS POŽIŪRIU
}

\author{
Vytautas Skučas, Kęstutis Skučas, Stanislovas Stonkus \\ Lietuvos kūno kultūros akademija, Kaunas, Lietuva
}

Vytautas Skučas. Lietuvos kūno kultūros akademijos reabilitacijos magistras. Mokslinių tyrimų kryptis — taikomoji fizinė veikla.

\section{SANTRAUKA}

Dèl diskusijos tarp tyrèju ir dèl tyrimu apie vežimèliu krepšinio specialiuosius fizinius gebëjimus, apie aerobini pajeguma ir žaidimo igūdžius trūkumo aktualūs ir reikšmingi moksliniai tyrimai, analizuojantys šiu rodikliu kaita negalios sunkumo laipsnio, amžiaus, žaidimo stažo požiūriu. Tyrimo tikslas - nustatyti ir ìvertinti vežimèliu krepšinio žaidèju specialiuju fiziniu gebëjimu, aerobinio pajègumo ir žaidimo igūidžiu rodikliu kaita pažeidimo laipsnio, amžiaus, žaidimo stažo požiūriu.

Specialiuju fiziniu gebèjimu ir žaidimo rodikliu testais buvo ištirti 42 vežimèliu krepšinio žaidèjai. Visi tiriamieji suskirstyti ̌ tris grupes pagal pažeidimo laipsni, amžiu ir žaidimo stažq. Tyrimo metu naudoti greitumo, vikrumo, anaerobinès ištvermès, kamuolio perdavimo tikslumo, kamuolio varymo, kamuolio metimu $\dot{z}$ krepš́ testai (Valandewijck et al., 1999; Skučas, Stonkus, 2001). Atliekant nenutrūkstama nuosekliai didinama fizini krūvi ranku ergometru „,Monark“, duju analizatoriumi „, Oxycon Mobile“, buvo ištirtas 21 vežimèliu krepšinio žaidèjas. Jie taip pat buvo suskirstyti i tris grupes pagal pažeidimo laipsni, amžiu ir žaidimo stažq. Nustatyti darbo galingumo, kvèpavimo, duju apykaitos, širdies susitraukimu dažnio rodikliai atliekant nenutrūkstama nuosekliai didinama fizini krūvì ranku ergometru „Monark" (sukimo dažnis - 70 aps. / min). Nešiojamuoju duju analizatoriumi „Oxycon Mobile“ nenutrūkstamai buvo registruojama plaučiu ventiliacija, kvépavimo dažnis, deguonies suvartojimas $\left(V_{2}\right)$, deguonies suvartojimas $1 \mathrm{~W}$ atliekamo darbo. Fizinis krūvis buvo didinamas, kol pasiekiama kritinio intensyvumo riba. Nustatytos aerobinio ir anaerobinio slenksčio bei kritinio intensyvumo ribos ir darbo galingumo, deguonies suvartojimo, širdies susitraukimu dažnio rodikliai ties šiomis ribomis.

Tyrimo rezultatai parodè, kad blogiausi vežimèliu krepšinio specialiuju fiziniu gebèjimu rodikliai žaidèju negalios sunkumo laipsnio požiūriu buvo 1-1,5 balo žaidèju grupès, lyginant su kitu grupiu duomenimis. Geriausi specialiuju fiziniu gebéjimu rodikliai pasiekti 25-35 m. amžiaus žaidèju (greitumas - 6,1 s, anaerobinè ištvermè - 92,1 m). Žaidimo vertinimo tyrimas atskleidè skirtinga žaidimo igūdž̌iu rodikliu kaita žaidèju negalios sunkumo laipsnio, amžiaus, žaidimo stažo požiūriu. Geriausi žaidimo igūdžiu rodikliai pasiekti 3-3,5 ir 4-4,5 balo žaidèju. Per vienerias rungtynes šie žaidèjai pelnè po 11-17 tašku, metimu i krepš̀ iš vidutiniu nuotoliu tikslumas siekè 37-40\%, atliko 18-20 kamuolio perdavimu. Žaidèju amžius iš esmès neturèjo itakos žaidimo igūdžiu rodikliu kaitai. Nustatyta, kad 6-10 metu ir didesnì staža turinčiu žaidèjužaidimo igūdžiu rodikliai yra geriausi. Per vienerias rungtynes šie žaidëjai pelne po 11 tašku, metimu i krepš́ iš vidutiniu nuotoliu tikslumas sieke 37\%, atliko 21 kamuolio perdavima.

Aerobinio pajegumo rodikliai atliekant ranku ergometrija kito skirtingai ir priklausè nuo žaidèju negalios sunkumo laipsnio, amžiaus, žaidimo stažo. Tyrimas parodè, kad 35-45 m. amžiaus žaidèju grupès aerobinio pajégumo rodikliai buvo blogiausi, lyginant su kitu grupiu duomenimis: $56,2 \mathrm{~W}$ darbo galingumas ties aerobiniu slenksčiu, 85,8 W- ties anaerobiniu slenksčiu, $148 \mathrm{~W}$ - ties kritine intensyvumo riba. Labiausiai pakito 6-10 metu ir didesnio stažo žaidèju aerobinio pajégumo rodikliai: 89,6 W darbo galingumas ties aerobiniu slenksčiu, 121,3 W-ties anaerobiniu slenksčiu, $181 \mathrm{~W}$ - ties kritine intensyvumo riba.

Raktažodžiai: vežimèliu krepšinis, specialieji fiziniai gebẻjimai, žaidimo rodikliai, aerobinis pajègumas.

\section{IVADAS}

$\mathrm{V}$ ežimėlių krepšinis - viena iš populiariausių neigaliujų sporto šakų. Tai labai svarbi neigaliuju fizinio ugdymo priemonè. Mokslininkai (Coubariaux, 1994; Valandewijck et al., 1999; Brasile, Hedrick, 1996; Skučas, Stonkus, 2001; Skučas, 2003; Brunelli et al., 2006), nagrinejjantys vežimèlių krepšinio problemas, ne kartą yra pažymėję, kad vežimėlių krepšinis padeda ugdyti fizines ypatybes ir specifinius vežimèlio valdymo igūdžius, kurie pagerina jų reabilitaciją bei socializaciją. Be to, vežimèliu krepšinis fiziškai neigaliems yra prieinama ir patraukli varžybu sporto šaka, suteikianti galimybę žaidejams tobulinti specialiuosius fizinius gebėjimus ir žaidimo 
igūdžius. Daugiausia fizinio ugdymo ir vežimèlių krepšinio, kaip varžybinio sporto klausimai, mokslinèje literatūroje nagrinèjami žaidejjų negalios tipo ir pažeidimo laipsnio požiūriu (Coubariaux, 1994; Valandewijck et al., 1999; Brunelli ir kt., 2006). Dažnai apsiribojama vien tik specialiujų fiziniu gebejjimų rodiklių analize, nenagrinèjant žaidimo igūdžių rodiklių. Visgi daugelis tyrimų rodo, kad vežimèliu krepšinio žaidejjų specialiuju fizinių ir žaidimo igūdžių rodikliai geresni lengvesnès negalios žaidèjų. Šie rodikliai pamažu blogèja, lyginant lengvesnès ir sunkesnès negalios žaidejjų rodiklius. Atsiranda tyrejjų (Valandjewick et al., 2003; Molik, Kosmol, 2001, 2003), teigiančių, kad ne visų vežimèlių krepšinio žaidejju pažeidimo laipsnis lemia specialiujų fizinių ir žaidimo igūdžių rodiklius. Šių tyrèjų duomenimis, mažiausi vežimèlių krepšinio specialiuju fizinių ir žaidimo igūdžių rodikliai pasiekti sunkiausios negalios vežimèliu krepšinio žaidèjų, o visų kitų rodikliai buvo panašūs. Dèl šių tyrimo duomenų skirtumo vis dar lieka neaišku, kaip vežimėlių krepšinio specialiuju fizinių ir žaidimo igūdžių rodikliai priklauso nuo negalios sunkumo laipsnio (vežimèlių krepšinio klasès). Todèl būtini îvairiapusiški tyrimai, kurie galètų atskleisti skirtingo pažeidimo vežimèlių krepšinio žaidejju fizinio pajègumo rodiklių kaitą. Šiuo požiūriu reikšmingi ne tik išoriniai tyrimai, parodantys vežimèlių krepšinio specialiujų fiziniu ir žaidimo igūdžių rodiklių išsiugdymo lygi, bet ir aerobinio pajègumo tyrimai, atliekami laboratorinèmis sąlygomis. Tyrèjai (Hedrick et al., 1994; Valandewijck et al., 1999; Skučas, Stonkus, 2002), nagrinèję vežimèlių krepšinio specialiujų fiziniu ir žaidimo igūdžių rodiklių kaitą, dažniausiai apsiriboja šių rodiklių analize tik negalios sunkumo laipsnio požiūriu pagal vežimèlių krepšinio žaidèjų klasifikacines klases ir nenagrinėja šių rodiklių kaitos amžiaus ir žaidimo stažo požiūriu. B. Molik, A. Kosmol (2003) tyrè, kaip vežimèlių krepšinio žaideju specialieji fiziniai gebėjimai priklauso nuo žaidimo stažo, tačiau tyrimo metu buvo naudoti tik keli standartizuoti testai specialiesiems fiziniams gebejimams vertinti ir nebuvo tirti žaidimo igūdžiu rodikliai. Todèl galima teigti, kad vis dar stokojama tyrimu, nagrinejjančių vežimèlių krepšinio specialiujų fizinių ir žaidimo igūdžių rodiklių kaitą amžiaus, žaidimo stažo požiūriu.

Taigi išlieka mokslinè problema, kelianti klausimą, ar vežimèlių krepšinio žaidėjų specialieji fiziniai gebejjimai, aerobinis pajègumas ir žaidimo igūdžiai priklauso nuo negalios sunkumo laipsnio, amžiaus, žaidimo stažo.
Tyrimo tikslas - nustatyti ir ịvertinti vežimèlių krepšinio žaidèjų fizinių ypatybių, aerobinio pajègumo ir žaidimo igūdžių rodiklių kaitą pažeidimo laipsnio, amžiaus, žaidimo stažo požiūriu.

Tyrimo objektas: vežimèlių krepšinio žaidèju fizinių ypatybių, aerobinio pajègumo ir žaidimo igūdžių rodiklių kaita.

\section{TYRIMO METODAI IR ORGANIZAVIMAS}

Naudoti šie tyrimo metodai: testavimas, pedagoginis stebėjimas, matematinè statistinè analizè. Testavimo metodu nustatyta vežimèliu krepšinio žaidimo igūdžių ir fizinių ypatybių priklausomybė nuo negalios sunkumo laipsnio, amžiaus, žaidimo stažo. Tyrimo metu naudoti greitumo, vikrumo, anaerobinès ištvermès, kamuolio perdavimo tikslumo, kamuolio varymo, kamuolio metimų i krepši testai (Valandewijck et al., 1999; Skučas, Stonkus, 2001).

Lietuvos kūno kultūros akademijos laboratorijoje buvo tirtas vežimėlių krepšinio žaidèju, turinčių nugaros smegenų pažeidimą, aerobinis pajègumas nustatant darbo galingumo, kvèpavimo, dujų apykaitos, širdies susitraukimų dažnio rodiklius, atliekant nenutrūkstamą nuosekliai didinamą fizinị krūvị rankų ergometru „Monark“. Pedalu sukimo dažnis - 70 aps. / min. Darbas buvo pradètas esant $7 \mathrm{~W}$ krūviui, po trijų minučiu kas $20 \mathrm{~s}$ darbo galingumas didinamas po $7 \mathrm{~W}$. Darbo metu nešiojamuoju dujų analizatoriumi „Oxycon Mobile" nenutrūkstamai buvo registruojama plaučių ventiliacija, kvėpavimo dažnis, deguonies suvartojimas $\left(\mathrm{VO}_{2}\right)$, deguonies suvartojimas $1 \mathrm{~W}$ atliekamo darbo. Fizinis krūvis buvo didinamas, kol pasiekiama kritinio intensyvumo riba. Nustatytos aerobinio ir anaerobinio slenksčio bei kritinio intensyvumo ribos, darbo galingumo, deguonies suvartojimo, širdies susitraukimų dažnio rodikliai ties šiomis ribomis.

Pedagoginio stebejjimo metodu nustatyti ir Ł̇vertinti vežimėlių krepšinio žaidejjų žaidimo igūdžiai. Skaitmenine vaizdo kamera „Panasonic NV-GS27“" nufilmuotos vežimèlių krepšinio Lietuvos čempionato ir tarptautinių varžybų rungtynès (stebètų rungtynių skaičius $-\mathrm{n}=20$ ). Rungtynèse žaide nacionaliniu ir tarptautiniu (šalies rinktinejje žaidžiantys žaidèjai) lygiu žaidžiantys vežimèliu krepšini žaidèjai. Vežimėlių krepšinio žaidejų žaidimo igūdžiai buvo vertinami remiantis B. Hendrick ir kt. (1994) metodika - už atskirus veiksmus aikšteje buvo skiriami teigiami arba neigiami 
taškai (Skučas, Stonkus, 2002). Duomenys apdoroti matematinès statistinès analizès būdu taikant statistinès duomenų analizès programą SPSS 12.0. Apskaičiuoti grupių aritmetiniai vidurkiai, ju paklaida. Skirtumo tarp tiriamu grupių aritmetinių vidurkių reikšmingumas vertintas naudojant Studento kriterijų (t). Pasirinktas reikšmingumo lygmuo, kai $\mathrm{p}<0,05$.

Testavimo ir stebejjimo metodu buvo tirti 42 vežimèliu krepšinio žaidejjai, pagal pažeidimo laipsni, amžiu ir žaidimo stažą suskirstyti i tris grupes. Pagal pažeidimo laipsni vežimèlių krepšinio žaidèjai, remiantis Tarptautine vežimèliu krepšinio klasifikacine sistema, buvo suskirstyti i keturias grupes: 1 -ai grupei priskirti $1-1,5$ balo 8 žaidejjai, turintys sunkią negalią; 2-ai $-2-2,5$ balo 15 žaidèjų; 3-iai $-3-3,5$ balo 8 žaidejjai; 4-ai - 4-4,5 balo 11 žaidèjų, turinčiu lengvesnę negalią. Pagal amžių vežimėlių krepšinio žaidejjai suskirstyti $\mathfrak{i}$ tris grupes: 1 -ai grupei priskirti 6 $15-25 \mathrm{~m}$. amžiaus, 2-ai - 22 25-35 m. žaidèjai, 3-iai - 14 35-45 ir daugiau metu turintys vežimèlių krepšinio žaidejai. Pagal žaidimo stažą vežimèlių krepšinio žaidèjai suskirstyti į tris grupes: 1-ai grupei priskirti 10 iki 2 metų, 2-ai -15 3-5 metu, 3-iai - 17 6-10 ir daugiau metu žaidžiantys vežimèliu krepšini. I grupes pagal amžių priskirti skirtingo žaidimo stažo (iki 10 metu) žaidejai.

Aerobiniam pajègumui įvertinti buvo ištirtas 21 vežimèlių krepšinio žaidèjas. Visi tiriamieji taip pat buvo suskirstyti $\mathfrak{i}$ tris grupes pagal negalios lygi, amžių ir žaidimo stažą. Pagal pažeidimo laipsnį vežimèlių krepšinio žaidejjai suskirstyti i keturias grupes: 1 -ai grupei priskirti $1-1,5$ balo 5 žaidejjai, pagal tarptautinę klasifikacinę sistemą turintys sunkią negalią; 2-ai $-2-2,5$ balo 6 žaidèjai; 3-iai - 3-3,5 balo 5 žaidèjai; 4-ai - 4-4,5 balo 5 žaidèjai, turintys lengvesnę negalią. Pagal amžių vežimèliu krepšinio žaidèjai suskirstyti i tris grupes: 1-ai grupei priskirti $815-25 \mathrm{~m}$., 2-ai - 8 25-35 m., 3-iai - 5 35-45 ir vyresni metų turintys vežimėlių krepšinio žaidejjai. Pagal žaidimo stažą vežimèlių krepšinio žaidèjai suskirstyti i tris grupes: 1 -ai grupei priskirti 5 iki 2 metų, 2-ai - $103-5$ metu, 3-iai - 6 6-10 ir daugiau metų stažo turintys vežimèlių krepšinio žaidejaai.

\section{REZULTATAI}

Atlikus tyrimą paaiškèjo, kad geriausių anaerobinès ištvermès $(92,1 \pm 5,4)$, greitumo $(6,1 \pm 0,19)$, metimu i krepši tikslumo $(28,95 \pm 7,74)$ rodikliu neigalieji žaidèjai pasiekia būdami $25-35 \mathrm{~m}$. amžiaus $(\mathrm{p}<0,05) .15-25$ ir $35-45 \mathrm{~m}$. žaidejų šie rodikliai (anaerobinès ištvermès $-84,37 \pm 9,07$ ir $82,4 \pm 6,4$; greitumo $-6,60 \pm 0,49$ ir $6,4 \pm 0,20$; metimu i krepši tikslumo - 23,85 $\pm 5,51$ ir 24,98 \pm 7,76) buvo panašūs.

Analizuojant ịvairu vežimèlių krepšinio žaidimo stažą turinčių neigaliujų specialiuosius fizinius gebėjimus (1 lent.) nustatyta, kad beveik visų testų (išskyrus vežimèlio ir kamuolio valdymo, kamuolio perdavimo tikslumo) blogiausių rodikliu pasiekè neiggalieji, žaidę vežimèlių krepšinį iki 2 metų, lyginant su didesnio stažo žaidejjų grupèmis.

Geriausių specialiujų fiziniu gebejjimų rodiklių pasiekè neigalieji, žaidę vežimèlių krepšini 6-10 m. Analizuojant specialiujų fiziniu gebèjimų rodiklius pagal tiriamujų negalios sunkumo laipsni nustatyta, kad blogiausių rodiklių pasiekė 1-1,5 balo (pagal Tarptautinès vežimèlių krepšinio federacijos klasifikacinę sistemą) neigalieji žaidejjai. Kitų klasių $2-2,5,3-3,5$ ir $4-4,5$ balo žaidèjų specialiujų fizinių gebèjimų rodikliai buvo panašūs (2 lent.).

Skirtingo negalios sunkumo vežimèlių krepšinio varžybinès veiklos tyrimai parode, kad $1-1,5$

\begin{tabular}{|c|c|c|c|c|c|}
\hline \multirow{5}{*}{$\begin{array}{l}1 \text { lentelè. Skirtingo žaidi- } \\
\text { mo stažo vežimėlių krep- } \\
\text { šinio žaidėjų specialiųjų } \\
\text { fizinių gebėjimų kaita }\end{array}$} & Testas & Rodiklis & Iki 2 m. & $3-5 \mathrm{~m}$. & $\begin{array}{l}\text { 6-10 m. ir } \\
\text { daugiau }\end{array}$ \\
\hline & 30 s važiavimo, $\mathrm{m}$ & Anaerobinė ištvermė & $83,27 *( \pm 9,07)$ & $90( \pm 6,7)$ & $91,4( \pm 6,2)$ \\
\hline & $20 \mathrm{~m}$ sprinto, $\mathrm{s}$ & Greitumas & $6,70 *( \pm 0,46)$ & $6,2 * *( \pm 0,19)$ & $6,1( \pm 0,18)$ \\
\hline & Važiavimo aštuonetu & Vikrumas & $14,3 *( \pm 1,51)$ & $16,54 * *( \pm 1,20)$ & $17,61( \pm 1,19)$ \\
\hline & $\begin{array}{l}\text { Kamuolio varymo } \\
\text { aštuonetu }\end{array}$ & $\begin{array}{l}\text { Vežimèlio ir kamuolio } \\
\text { valdymas }\end{array}$ & $11,70( \pm 1,53)$ & $12,89( \pm 1)$ & $13,90( \pm 0,9)$ \\
\hline \multirow{3}{*}{$\begin{array}{l}\text { Pastaba. * _ rodiklių skir- } \\
\text { tumas statistiškai patiki- } \\
\text { mas }(\mathrm{p}<0,05) \text { tarp iki } 2 \text { ir } \\
6-10 \mathrm{~m} . \text { ir didesnio stažo } \\
\text { žaidejju grupių; ** - rodi- } \\
\text { klių skirtumas statistiškai } \\
\text { patikimas }(\mathrm{p}<0,05) \text { tarp } \\
\text { iki } 2 \text { ir } 3-5 \mathrm{~m} . \text { stažo žai- } \\
\text { dejų grupių. }\end{array}$} & $\begin{array}{l}\text { Tolimų metimų i krepši } \\
\text { testas }\end{array}$ & $\begin{array}{l}\text { Tolimų metimų i krepši } \\
\text { tikslumas }\end{array}$ & $11,68^{*}( \pm 2,75)$ & $14,5 * *( \pm 5,92)$ & $16,9( \pm 5,82)$ \\
\hline & $\begin{array}{l}\text { Metimų i krepši iš arti- } \\
\text { mų ir vidutinių nuotolių }\end{array}$ & $\begin{array}{l}\text { Metimo i krepši tiks- } \\
\text { lumas }\end{array}$ & $21,78( \pm 5,41)$ & $28,9 * *( \pm 7,68)$ & $29,1( \pm 7,78)$ \\
\hline & $\begin{array}{l}\text { Kamuolio perdavimo } \\
\text { testas }\end{array}$ & $\begin{array}{l}\text { Kamuolio perdavimo } \\
\text { tikslumas }\end{array}$ & $27,5( \pm 5,78)$ & $32,1( \pm 9,69)$ & $32,9( \pm 9,75)$ \\
\hline
\end{tabular}




\begin{tabular}{|c|c|c|c|c|c|}
\hline Testas & Rodiklis $\quad$ Balai & $1-1,5$ & $2-2,5$ & $3-3,5$ & $4-4,5$ \\
\hline $30 \mathrm{~s}$ važiavimo, $\mathrm{m}$ & Anaerobinè ištvermè & $69,85^{*} \pm 9,05$ & $76,84 \pm 7,38$ & $76,96 \pm 8,12$ & $79,974 \pm 7,21$ \\
\hline $20 \mathrm{~m}$ sprinto, $\mathrm{s}$ & Greitumas & $7,21 * \pm 0,45$ & $6,25 \pm 0,27$ & $6,59 \pm 0,55$ & $6,35 \pm 0,28$ \\
\hline Važiavimo aštuonetu & Vikrumas & $15,74^{*} \pm 1,81$ & $17,43 \pm 1,71$ & $17,64 \pm 1,51$ & $17,71 \pm 1,24$ \\
\hline $\begin{array}{l}\text { Kamuolio varymo } \\
\text { aštuonetu }\end{array}$ & $\begin{array}{l}\text { Vežimèlio ir kamuo- } \\
\text { lio valdymas }\end{array}$ & $12,67^{*} \pm 1,51$ & $15,72 \pm 1,02$ & $15,85 \pm 1,24$ & $15,93 \pm 1,03$ \\
\hline $\begin{array}{l}\text { Tolimų metimų i krepši } \\
\text { testas }\end{array}$ & $\begin{array}{l}\text { Tolimų metimų } i \\
\text { krepšį tikslumas }\end{array}$ & $9,57 * \pm 2,28$ & $10,52 \pm 2,11$ & $11,32 \pm 3,59$ & $11,78 \pm 3,82$ \\
\hline $\begin{array}{l}\text { Metimų i krepšsi iš arti- } \\
\text { mų ir vidutinių nuotolių }\end{array}$ & $\begin{array}{l}\text { Metimo i krepši } \\
\text { tikslumas }\end{array}$ & $36,78^{*} \pm 5,34$ & $42,74 \pm 4,25$ & $47,36 \pm 5,85$ & $51,14 \pm 7,05$ \\
\hline $\begin{array}{l}\text { Kamuolio perdavimo } \\
\text { testas }\end{array}$ & $\begin{array}{l}\text { Kamuolio perdavi- } \\
\text { mo tikslumas }\end{array}$ & $27,74^{*} \pm 5,94$ & $28,41 \pm 4,23$ & $30,58 \pm 7,61$ & $31,92 \pm 6,19$ \\
\hline
\end{tabular}

2 lentelè. Skirtingos fizinès negalios vežimèlių krepšinio žaidėjų specialiųjų fizinių gebèjimų kaita

\begin{tabular}{|c|c|c|c|c|c|c|}
\hline \multirow{2}{*}{\multicolumn{3}{|c|}{$\begin{array}{|ll|}\text { Balai } & \\
& \text { Vidurkis }\end{array}$}} & \multirow{2}{*}{$\begin{array}{c}\mathbf{1}-\mathbf{1 , 5} \\
\overline{\mathrm{x}}\end{array}$} & \multirow{2}{*}{$\begin{array}{c}2-2,5 \\
\bar{x}\end{array}$} & \multirow{2}{*}{$\begin{array}{c}3-\mathbf{3 , 5} \\
\bar{x}\end{array}$} & \multirow{2}{*}{$\begin{array}{c}\mathbf{4 - 4 , 5} \\
\bar{x}\end{array}$} \\
\hline & & & & & & \\
\hline \multicolumn{3}{|c|}{ Žaidimo trukmè, min } & 29 & 34 & 36 & 39 \\
\hline \multicolumn{3}{|c|}{ Kamuolio perdavimai } & 7 & 10 & 18 & 20 \\
\hline \multicolumn{3}{|c|}{ Varymas } & 3,8 & 10 & 12 & 20 \\
\hline \multirow{9}{*}{$\begin{array}{l}\text { Metimai i } \\
\text { krepši }\end{array}$} & \multirow{3}{*}{$\begin{array}{l}\text { Iš artimo ir vi- } \\
\text { dutinio nuotolio }\end{array}$} & Metè & 4 & 8 & 10 & 17 \\
\hline & & Imetè & 1,6 & 2,4 & 5,4 & 7,8 \\
\hline & & Tikslumas, $\%$ & 30 & 31 & 37 & 40 \\
\hline & \multirow{3}{*}{ Iš toli } & Metè & 0 & 0,5 & 0,6 & 1 \\
\hline & & Imetè & 0 & 0 & 0,1 & 0,3 \\
\hline & & Tikslumas, $\%$ & 0 & 0 & 14 & 33 \\
\hline & \multirow{3}{*}{ Iš viso } & Meté & 4 & 8,5 & 10,6 & 18 \\
\hline & & Imetè & 1,6 & 2,4 & 5,5 & 8,1 \\
\hline & & Tikslumas, $\%$ & 30 & 30 & 34 & 36 \\
\hline \multirow{3}{*}{\multicolumn{2}{|c|}{ Baudos metimai }} & Mete் & 1 & 1 & 2 & 5 \\
\hline & & Imetè & 0 & 0,4 & 0,6 & 1,7 \\
\hline & & Tikslumas, $\%$ & 0 & 40 & 38 & 40 \\
\hline \multicolumn{3}{|c|}{ Pelnyti taškai } & 2 & 5 & 11 & 17 \\
\hline \multicolumn{3}{|c|}{ Atkovoti kamuoliai } & 2 & 3 & 3 & 7 \\
\hline \multicolumn{3}{|c|}{ Asmeninės pražangos } & 1 & 2 & 2 & 1 \\
\hline \multicolumn{3}{|c|}{ Rezultatyvūs perdavimai } & 1 & 1 & 2 & 1 \\
\hline \multicolumn{3}{|c|}{ Technikos klaidos } & 2 & 1 & 2 & 2 \\
\hline \multicolumn{3}{|c|}{ Metimų blokavimai } & 0 & 1 & 2 & 2 \\
\hline \multicolumn{3}{|c|}{ Perimti kamuoliai } & 1 & 1 & 2 & 2 \\
\hline \multicolumn{3}{|c|}{ Užtvaros } & 2 & 3 & 2 & 2 \\
\hline \multicolumn{3}{|c|}{ Prasiveržimai } & 1 & 1 & 1 & 2 \\
\hline
\end{tabular}

Pastaba. * — rodikliu skirtumas statistiškai patikimas $(\mathrm{p}<0,05)$ tarp $1-1,5$ balo ir kitų grupių žaidèjų.

3 lentelè. Skirtingos negalios vežimèliụ krepšinio žaidèjụ žaidimo rodiklių vidurkis per vienerias rungtynes

ir 2-2,5 balo žaidèjai atliko mažiausiai techninių veiksmu, išsiskyrè 3-3,5 ir 4-4,5 balo žaidèjai. Jų žaidimo per rungtynes rodikliai buvo geriausi (3 lent.).

Skirtingo amžiaus vežimėlių krepšinio žaidejjų varžybinès veiklos tyrimai parodè, kad žaidejų amžius žaidimo rodiklių kaitos iš esmès nepaveikè.

Skirtingo žaidimo stažo vežimėlių krepšinio žaidejjų varžybinès veiklos tyrimai parodè, kad žaidèjų, kurių stažas yra 6-10 ir daugiau metu, žaidimo rodikliai buvo geriausi. Šie žaidejai vidutiniškai per vienerias rungtynes daugiau perdavė kamuolių (21), geriau varè kamuoli (13), metè $i$ krepši $(12,6)$, tiksliau mètė iš artimo ir vidutinio nuotolio (34\%), pataikè baudos metimus (38\%), lyginant su kitų skirtingo stažo žaidejjų grupių rodikliais.

Atlikus skirtingo amžiaus vežimèlių krepšinio žaidèjų aerobinio pajègumo tyrimą paaiškèjo, kad $35-45 \mathrm{~m}$. amžiaus žaidejų grupès aerobinio pajègumo rodikliai buvo blogiausi, lyginant su kitų grupių duomenimis. Nustatyti didžiausi darbo galingumo rodiklių skirtumai tarp $35-45 \mathrm{~m}$. ir kitų tirtų amžiaus grupių žaidèjų (1 pav.).

Išanalizavus skirtingo žaidimo stažo žaidèjų ŠSD, darbo galingumo, deguonies suvartojimo rodiklius skirtingose energijos gamybos zonose buvo pastebèta, kad aerobinio pajègumo rodikliai geriausi yra 6-10 metų ir didesni stažą turinčių žaidèjų. 
1 pav. Skirtingo amžiaus vežimèlių krepšinio žaidèjų darbo galingumas skirtingose energijos gamybos zonose

Pastaba. * - statistiškai patikimas $(\mathrm{p}<0,05)$ skirtumas tarp $35-45 \mathrm{~m}$. amžiaus ir kitų grupių.

2 pav. Skirtingos negalios vežimèlių krepšinio žaidèjų deguonies suvartojimas skirtingose energijos gamybos zonose
Pastaba. * _ rodiklių skirtumas statistiškai patikimas $(\mathrm{p}<0,05)$ tarp $1-1,5$ balo ir kitu grupių žaidèjų.
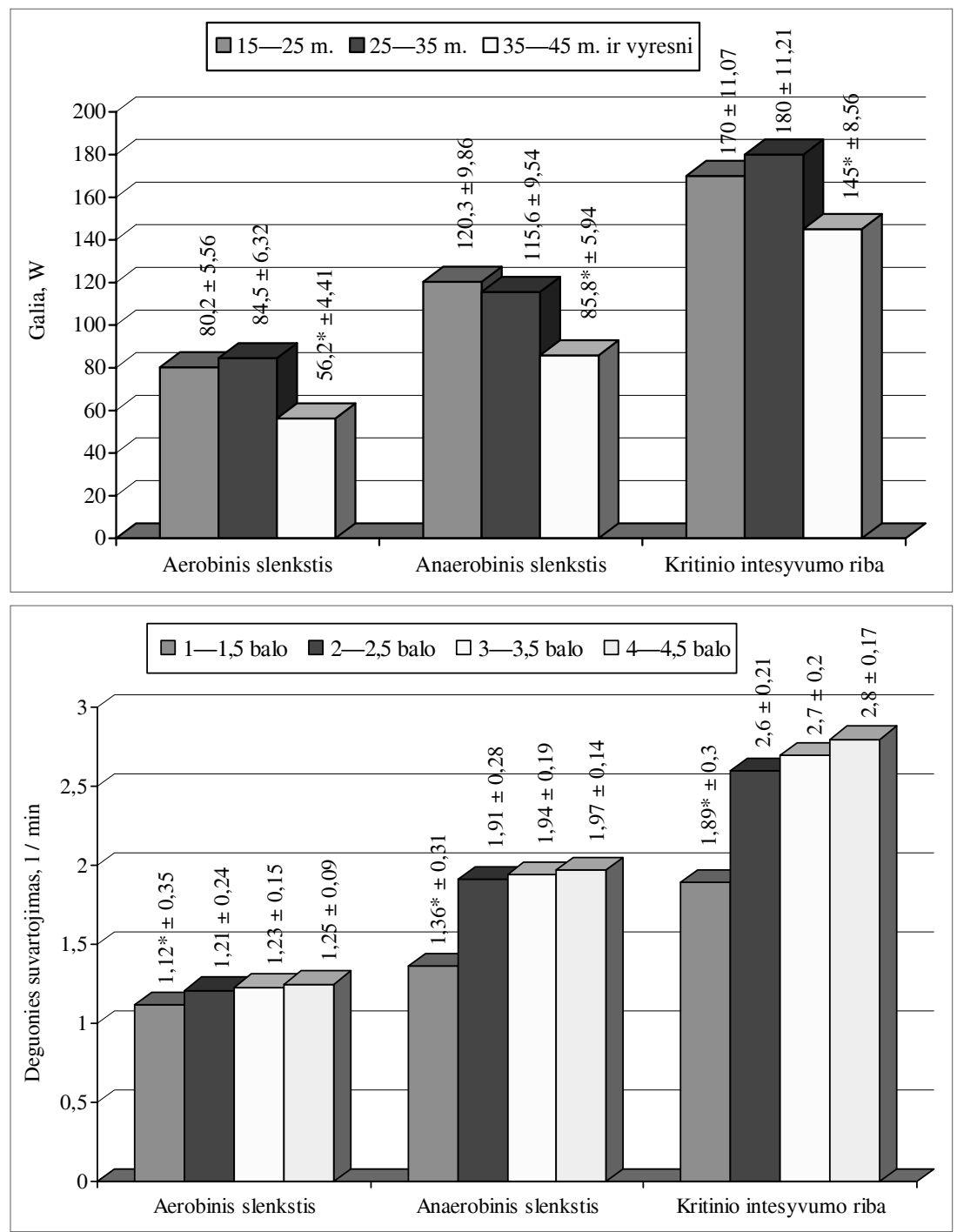

Ivertinus skirtingos negalios vežimėlių krepšinio žaidejų deguonies suvartojimo (2 pav.), ŠSD, darbo galingumo rodiklius skirtingose energijos gamybos zonose nustatyta, kad blogiausi yra $1-1,5$ balo žaidèjų grupès, lyginant su kitų grupių duomenimis.

\section{REZULTATUQ APTARIMAS}

Vežimèlių krepšinio specialiuju gebėjimų tyrimai rodo vežimèlių krepšinio žaidèjų fizinių ypatybių ir specialiujų fizinių gebèjimų išugdymo lygi. Daugumos autorių duomenimis (Valandewijck et al., 1999, 2003; Skučas, Stonkus, 2001; 2002; Skučas, 2003), specialieji fiziniai vežimèlių krepšinio žaidejjų gebejjimai priklauso nuo žaidejjų meistriškumo, pažeidimo laipsnio, žaidimo stažo ir beveik nepriklauso nuo amžiaus. Mūsuc tyrimo duomenimis, vežimèlių krepšinio žaidejju specialieji gebejjimai daugiausia priklauso nuo meistriškumo, mažiau nuo pažeidimo laipsnio, žaidimo stažo ir amžiaus. Didžiausi skirtumai tarp šių grupių rodiklių nustatyti vertinant aerobinę, anaerobinę ištvermę, vikrumą, kamuolio varymą ir metimus i krepši

Atlikto tyrimo duomenys sutampa su panašaus pobūdžio kitų autoriu gautais, kurie teigia, kad vežimèlių krepšinio žaidejjų stažas turi įtakos vežimèlių krepšinio fizinių gebėjimų rodikliams. Geriausių rodiklių pasiekè 6-10 metu ir didesni stažą turintys žaidejjai. Tai rodo, kad pasiekti vežimèlių krepšinio specialiuju gebejjimu puikių rodiklių, ypač sunkios negalios žaidèjams $(1-1,5$ balo), reikia žaisti vežimèlių krepšinị ilgesnị laiką, nes vežimèliu krepšinio specialiuosius fizinius gebejjimus lemia ne tik fiziniu ypatybių išsiugdymo lygis, bet ir vežimèlio varymo valdymo technika, o šito pasiekiama per ilgesni laiką.

Vežimėlių krepšinio specialiujų fizinių gebèjimų rodikliai negalios sunkumo laipsnio požiūriu skyrèsi tik tarp sunkiausios negalios ir mažiausių pakenkimų grupès. Visų kitu grupių rodikliai buvo panašūs. Šie duomenys sutampa su kitų tyrèjų (Molik, Kosmol, 2003; Valandjewick et 
al., 2003) gautaisiais, kurie teigia: skirtinga pažeidimą turinčiu vežimėlių krepšinio žaideju judejjimo igūdžius ir sèdejjimo tvirtumą vežimèlyje lemia geras vežimèlio pritaikymas ir papildomos kompensacinès technikos priemonès, naudojamos sunkios negalios žaidejjų. Tai patvirtina kitų autoriu atlikti tyrimai (Coubariaux, 1994; Brasile, Hedrick, 1996), nagrinejjantys vežimèlio pritaikymo poveiki vežimèlių krepšinio specialiesiems gebejjimams.

Vežimėlių krepšinio specialiujų fizinių gebèjimų tyrimas amžiaus požiūriu parode, kad amžius mažai lemia vežimèlių krepšinio žaidejjų specialiuosius gebejjimus. Geriausi vežimèlių specialiųjų fizinių gebejjimų rodikliai pasiekti $25-35 \mathrm{~m}$. amžiaus žaidejjų. Taigi vežimėlių krepšinyje labai svarbu išugdyti specialiuosius vežimèlių krepšinio gebejjimus, nuo kurių labiausiai priklauso žaidimo kokybė. Fizinès ypatybès, kurių išugdymo galimybès priklauso nuo amžiaus, nėra tokios svarbios žaidžiant vežimèlių krepšini.

Vežimėlių krepšinio varžybinès veiklos tyrimas parode, kad žaidimo kiekybiniai ir kokybiniai rodikliai priklauso nuo negalios sunkumo laipsnio. Daugiausia veiksmų per rungtynes atlieka nedidelę ir mažiausią negalią turintys $(3-3,5$ ir $4-4,5$ balo) žaidèjai. Jie atlieka daugiausia kamuolio perdavimų, metimu i krepši, geriau negu kitu klasių žaidejjai varo kamuolị. Kur kas mažiau veiksmų, lyginant su kitomis klasemis, atlieka sunkiausios ( $1-1,5$ balo) ir sunkios negalios $(2-2,5$ balo) žaidejjai. Geresnius nedidelès negalios $(3-3,5$ ir $4-4,5$ balo) žaidèjų žaidimo igūdžiu rodiklius galèjo lemti tai, kad mažesnès negalios vežimèliu krepšinio žaidejjai žaidžia arčiau krepšio puldami ir gindamiesi, dauguma jų išsikelia vežimèlio sẻdynę i didžiausią leistiną aukšti (iki $53 \mathrm{~cm}$ matuojant nuo grindu), dèl to sunkiau sutrukdyti jiems mesti kamuoli i krepši. Be to, nedidelès negalios žaidejjai (3-3,5 ir $4-4,5$ balo) gerai valdo liemeni, tvirtai sèdi vežimèlyje ir nepraranda pusiausvyros mesdami kamuoli i krepši.

Vežimèlių krepšinio varžybinès veiklos rodikliai skyrèsi priklausomai nuo žaidimo stažo, amžiaus požiūriu buvo panašūs.

Aerobinio pajėgumo rodikliai atliekant ranku ergometriją kito skirtingai ir priklausė nuo žaidèjų negalios sunkumo laipsnio, amžiaus, žaidimo stažo. Atlikto tyrimo duomenys buvo panašūs, lyginant su kitų tyrèju gautaisiais (Haisman et al., 2006), kurie nustate, kad aerobinio pajègumo rodikliai skirtingi ir priklauso nuo pažeidimo sunkumo. Blogiausius $1-1,5$ balo žaidèjų grupès aerobinio pajègumo rodiklius, lyginant su kitų grupių duomenimis, nustate ir kiti autoriai (Vanlandewijck et al., 2003). Tai dar kartą patvirtina, kad sunkiausios negalios vežimèliu krepšinio žaidejai nepasiekia didesnių fizinio pajègumo rodiklių, lyginant su lengvesnès negalios žaidejuc duomenimis. Kitu grupių (2-2,5, 3-3,5 ir $4-4,5$ balo) žaidejų aerobinio pajègumo rodikliai skyrèsi nedaug. Vadinasi, 1-1,5 balo žaidejjai, kurių nugaros smegenų pažeidimas dažniausiai būna ties Th1-7 segmentais, turi liemens pusiausvyros sutrikimų, širdies ir kraujagyslių, kvėpavimo sistemu sutrikimų, trukdančiu jiems pasiekti aukščiausių aerobinio pajègumo testo rodiklių.

Atlikto tyrimo duomenys patvirtina kitu tyrimų gautuosius (Hutzler et al., 2000) - aerobinio pajègumo rodikliai priklauso nuo amžiaus. Tačiau tyrimas amžiaus aspektu parodè, kad tik vyriausios 35-45 metu amžiaus žaidèjų grupès aerobinio pajègumo rodikliai buvo blogiausi, lyginant su kitu grupiu ( $15-25$ ir $25-35 \mathrm{~m}$.) duomenimis.

Žaidèjų aerobinio pajègumo rodikliai priklauso nuo žaidimo stažo. Daugiausia aerobinio pajègumo rodiklius lèmé žaidèjų (6-10 metų ir didesnis) stažas. Tai rodo, kad treniruojantis ir žaidžiant vežimèlių krepšini geresnių aerobinio pajègumo rodikliu galima pasiekti tik per ilgesni laiką $(6-10$ metuc ir daugiau).

\section{IŠVADOS}

1. Gauti skirtingi vežimèlių krepšinio specialiujų fizinių gebejjimų rodikliai žaidejų negalios sunkumo laipsnio, amžiaus, žaidimo stažo požiūriu:

- vežimèlių specialiujų fiziniu gebėjimų rodikliai blogesni sunkiausios negalios $1-1,5$ balo žaidejų grupès, lyginant su kitų grupių duomenimis;

- geriausi vežimèlių specialiujų fizinių gebèjimų rodikliai pasiekti $25-35 \mathrm{~m}$. amžiaus žaidèjų;

- specialiujų fizinių gebejjimų rodikliai pamažu gerèjo priklausomai nuo žaidèjų stažo.

2. Žaidimo vertinimo tyrimas atskleidè skirtingą žaidimo igūdžių rodiklių kaitą žaidejjų negalios sunkumo laipsnio, amžiaus, žaidimo stažo požiūriu:

- geriausių žaidimo igūdžių rodikliu pasiekè $3-3,5$ ir 4-4,5 balo žaidèju grupès;

- žaidejjų amžius iš esmès neturèjo itakos žaidimo igūdžių rodiklių kaitai; 
- žaidejjų stažas (6-10 metų ir didesnis) daugiausia lèmé žaidimo igūdžių rodiklius.

3. Aerobinio pajègumo rodikliai atliekant ranku ergometriją kito skirtingai ir priklausè nuo žaidèjų negalios sunkumo laipsnio, amžiaus, žaidimo stažo:

- blogiausi aerobinio pajègumo rodikliai buvo $1-1,5$ balo žaidejju grupès, lyginant su kitu grupių duomenimis;
- 35-45 m. amžiaus žaidèju grupès aerobinio pajègumo rodikliai buvo blogiausi, lyginant su kitu grupių duomenimis;

- 6-10 metų ir didesni stažą turintys žaidèjai pasiekè geriausiu aerobinio pajègumo rodiklių.

\section{LITERATŪRA}

Brasile, F. M., Hedrick, B. N. (1996). The relationship of skills of elite wheelchair basketball competitors to the international functional classification system. Therapeutic Recreation Journal, 30 (2), 114-127.

Brunelli, S., Traballesi, M., Averna, T. et al. (2006). Field Tests For Evaluating Elite Wheelchair Basketball Players. Rome.

Coubariaux, B. (1994). Wheelchair Athletes Classification System. IWBF.

Haisman, J. A., van der Woude, L. H. V., Stam, H. J. (2006). Physical capacity in wheelchair-dependent persons with a spinal cord injury: A critical review of the literature. Spinal Cord, 44, 642-652.

Hedrick, B., Byrnes, D., Shaver, L. (1994). Wheelchair Basketball (2nd Ed.). Paralyzed Veterans of America.

Hutzler, Y., Valandewijck, Y., Van Vierbeghe, M. (2000). Anaerobic Performance of Older Female and Male Wheelchair Basketball Players on a Mobile Wheelchair Ergometer. Adapted Physical Activity Quarterly, 17 (4), $250-2465$.

Molik, B., Kosmol, A. (2001). In search of objective criteria in wheelchair basketball player classification. In G. Doll-Tepper, M. Kroner, W. Sonnenschein (Eds.). Vista' '99-New Horizons in Sport for Athletes with a Disability. Proceedings of the International Vista '99 conference (pp. 355-368). Koln, Germany: Meyer \& Meyer.
Molik, B., Kosmol, A. (2003). Physical ability and playing skills criteria for classifying basketball wheelchair players. Wychowanie fizyczne I sport, 3 (46), 256-261.

Neumann, H. (1990). Basketball Training: Taktik — Technic - Condition. Germany: Meyer und Meyer Verlag.

Skučas, K., Stonkus, S. (2002). Ivairių amplua vežimėliu krepšinio žaidejju žaidimo rodikliai. Sporto mokslas, $1(27), 69-72$.

Skučas, K., Stonkus, S. (2001). Vežimèlių krepšinio žaidejų kai kurių fizinių ypatybių ir žaidimo igūdžių tyrimai. Ugdymas. Kūno Kultūra. Sportas, 4 (41), 74-80.

Skučas, K., (2003). Taikomosios fizinès ir sportinès veiklos vaidmuo fiziškai neigaliuju socializacijoje: daktaro disertacija. Šiauliai: Šiaulių universitetas.

Valandewijck, Y. C., Daly, D. J., Theisen, D. M. (1999). Field Test Evaluation of Aerobic, Anaerobic and Wheelchair Basketball Skill Performances. International Journal of Sports Medicine, 20, 1-7.

Valandewijck, Y. C, Evaggelinou, C., Daly D. et al. (2003). Proportionality in Wheelchair Basketball Classification. Adapted Physical Activity Quarterly, 20 (4), 456-462.

Wooten, M. (1992). Coaching Basketball Successfully. Champaign, IL: Leisure Press. 


\title{
CHANGES IN VALUES OF SPECIAL PHYSICAL ABILITIES, AEROBIC PERFORMANCE AND PLAYING SKILLS OF WHEELCHAIR BASKETBALL PLAYERS IN RELATION TO THEIR DISABILITY, AGE AND PLAYING EXPERIENCE
}

\author{
Vytautas Skučas, Kęstutis Skučas, Stanislovas Stonkus \\ Lithuanian Academy of Physical Education, Kaunas, Lithuania
}

\begin{abstract}
There is much discussion among researchers and lack of research in respect to special physical abilities, aerobic performance and playing skills of wheelchair basketball players. However, is actual and relevant scientific research analyzing these problems in the aspects of players' age, disability and time playing wheelchair basketball.

The aim of the research was to determine and evaluate special physical abilities, aerobic performance and playing skills of weelchair basketball players according to the playing experience, age and disability. Methods of testing and pedagogical observation were used, and 42 wheelchair basketball players participating in wheelchair basketball competitions were investigated. The participants of the research were divided into different groups according to their age, disability and time playing wheelchair basketball. The wheelchair basketball players participating in the research were divided ccording to the International wheelchair basketball classification system: eight $1-1.5$ point players, fifteen $2-2.5$ point players, $8-3-3.5$ point players, $11-4-4.5$ point players. Speed, quickness, anaerobic endurance, basket shooting, passing accuracy tests were used in the study (Valandewijck, Daly, Theisen, 1999; Skučas, Stonkus, 2001). Research method. Constantly increasing continuous physical load was applied to 21 wheelchair basketball players using an arm ergometer "Monark". Wheeling frequency was 70 times / min (rotations). The gas analyzer "Oxycon Mobile" was used during the physical performance to continuously register pulmonary ventilation, respiratory frequency, oxygen consumption $\left(\mathrm{VO}_{2}\right)$, the capacity of performance $(\mathrm{W})$. Physical load was increased until maximal intensity zone. Thresholds and maximal intensity zones of power, maximal heart rate, $\mathrm{VO}_{2}$ values were determined. The results of the research revealed that the values of special physical abilities of $1-1.5$ point players were different in comparison with other groups. The best results of special physical abilities were achieved in the 25-35 years of age group players and depended on different time of playing wheelchair basketball (speed - 6.1 s; anaerobic endurance - 92.1 m). The best wheelchair basketball playing skills results were achieved in the groups of $3-3.5$ and $4-4.5$ points players. These players scored $11-17$ points, their shooting accuracy was $37-40 \%$, and they made $18-20$ passes per game. Age did not influence wheelchair basketball playing skills of the players. The playing time in the group of $6-10$ years and more most influenced wheelchair basketball playing skills of the players. These players scored 11 points, their shooting accuracy was $37 \%$, and they made 21 passes per game. The investigation showed that the worst aerobic performance values were among the players in the groups of 35-45 year old players in comparison with other age groups: $56.2 \mathrm{~W}$ work power on aerobic threshold, $85.8 \mathrm{~W}$ on anaerobic threshold, $148 \mathrm{~W}$ on critical intensity zone. The playing time of the group of 6-10 years and more most influenced the values of aerobic performance: $89.6-\mathrm{W}$ work power on aerobic threshold, $121.3 \mathrm{~W}$ on anaerobic threshold, $181 \mathrm{~W}$ on critical intensity zone.
\end{abstract}

Keywords: wheelchair basketball, special physical abilities, playing skills, aerobic performance.

Gauta 2008 m. gegužès $1 \mathrm{~d}$.

Received on May 1, 2008

Priimta 2008 m. birželio $18 \mathrm{~d}$.

Accepted on June 18, 2008
Vytautas Skučas

Lietuvos kūno kultūros akademija

(Lithuanian Academy of Physical Education)

Sporto g. 6, LT-44221 Kaunas

Lietuva (Lithuania)

$\mathrm{Tel}+37037302660$

E-mail k.skucas@lkka.lt 